\title{
The relationship between the microstructures and catalytic behaviors of iron-oxygen precursors during direct coal liquefaction
}

\author{
Jing Xie a,b, Hanfeng Lu a,*, Geping Shu b, Kejian Li b, Xuwen Zhang b, Hongxue Wang b, Wang Yue a, \\ Shansong Gao b, Yinfei Chen a,\# \\ a College of Chemical Engineering, Zhejiang University of Technology, Hangzhou 310014, Zhejiang, China \\ b National Engineering Laboratory for Direct Coal Liquefaction, China Shenhua Coal to Liquid and Chemical Shanghai Research Institute, Shanghai \\ 201108, China
}

\section{A R T I C L E I N F O}

Article history:

Received 25 November 2017

Accepted 19 December 2017

Published 5 April 2018

\section{Keywords:}

Direct coal liquefaction

Iron-oxygen compound

Coal-supported catalyst

Synthesis temperature

Iron-based catalyst

\begin{abstract}
A B S T R A C T
A series of both unsupported and coal-supported iron-oxygen compounds with gradual changes in microstructure were synthesized by a precipitation-oxidation process at 20 to $70{ }^{\circ} \mathrm{C}$. The relationship between the microstructures and catalytic activities of these precursors during direct coal liquefaction was studied. The results show that the microstructure could be controlled through adjusting the synthesis temperature during the precipitation-oxidation procedure, and that compounds synthesized at lower temperatures exhibit higher catalytic activity. As a result of their higher proportions of $\gamma$ - $\mathrm{FeOOH}$ or $\alpha$ - $\mathrm{FeOOH}$ crystalline phases, the unsupported iron-oxygen compounds synthesized at $20-30^{\circ} \mathrm{C}$, which also had high specific surface areas and moisture levels, generate oil yields $4.5 \%-4.6 \%$ higher than those obtained with precursors synthesized at $70{ }^{\circ} \mathrm{C}$. It was also determined that higher oil yields were obtained when the catalytically-active phase formed by the precursors during liquefaction (pyrrhotite, $\mathrm{Fe}_{1-x} \mathrm{~S}$ ) had smaller crystallites. Feed coal added as a carrier was found to efficiently disperse the active precursors, which in turn significantly improved the catalytic activity during coal liquefaction.
\end{abstract}

(C) 2018, Dalian Institute of Chemical Physics, Chinese Academy of Sciences. Published by Elsevier B.V. All rights reserved.

\section{Introduction}

Direct coal liquefaction (DCL) is an effective method of utilizing coal to produce clean liquid fuels, especially for those countries that have limited oil resources but are rich in coal, such as China [1-3]. Oil yield is a key performance index for the DCL process, and 1\% increase in oil yield can result in 20000 tons of additional oil production or approximately 100 million RMB of additional profit for an industrial-scale DCL plant with a one million ton annual production capacity. A high-perfor- mance DCL catalyst can accelerate the pyrolysis of coal and promote the hydrocracking of macromolecular fragments, resulting in higher coal conversion and increased liquefied oil yield [4-6].

Iron-based materials applied as disposal catalysts during DCL have been widely employed due to their lower costs and moderate activities [7-11]. Pyrrhotite $\left(\mathrm{Fe}_{1-x} \mathrm{~S}\right)$, which is generated from iron-based catalysts during liquefaction, has been identified as the catalytically-active phase [12-15]. Red mud, natural iron ore, synthetic iron sulfide, synthetic iron oxides

\footnotetext{
* Corresponding author. Tel/Fax: +86-571-88320767; E-mail: luhf@zjut.edu.cn

\# Corresponding author. E-mail: yfchen@zjut.edu.cn

This work was supported by the Science and Technology Department of China Shenhua Group (MZY-13-12) and the National Key Research and Development Program of China (2016YFB0600303).

DOI: 10.1016/S1872-2067(17)62919-X | http://www.sciencedirect.com/science/journal/18722067 | Chin. J. Catal., Vol. 39, No. 4, April 2018
} 
Table 1

Proximate, ultimate and petrographical analysis data for the Shenhua Shangwan coal.

\begin{tabular}{|c|c|c|c|c|c|c|c|c|c|c|}
\hline \multicolumn{3}{|c|}{$w(\mathrm{wt} \%)$} & \multicolumn{3}{|c|}{$\varphi(\operatorname{vol} \%)$} & \multicolumn{5}{|c|}{$w\left(\right.$ element) ${ }^{\mathrm{a}}(\mathrm{wt} \%)$} \\
\hline$M_{\mathrm{ad}}$ & $A_{\mathrm{d}}$ & $V_{\text {daf }}$ & Vitrinite & Inertinite & Exinite & $\mathrm{C}$ & $\mathrm{H}$ & $\mathrm{O}^{\mathrm{b}}$ & $\mathrm{N}$ & $\mathrm{S}$ \\
\hline 4.46 & 5.86 & 34.89 & 54.2 & 44.2 & 0.4 & 79.16 & 4.38 & 15.21 & 0.98 & 0.27 \\
\hline
\end{tabular}

$M_{\mathrm{ad}}$-Air-dried moisture; $A_{\mathrm{d}}$-Dry ash; $V_{\text {daf }}$-Volatiles on a dry-ash-free basis. ${ }^{\text {a }}$ On a dry ash-free basis. ${ }^{\mathrm{b}}$ Determined by difference.

and oil- or water-soluble iron-containing materials have all been used in DCL. However, variations in properties such as crystalline phase, structure or dispersion will lead to pronounced differences in the resulting pyrrhotite and thus the catalytic activity [16-18].

Because DCL is a complicated three-phase reaction, it is very difficult to determine the relationship between catalytic precursors and oil yields. Linehan et al. [19] studied 11 different iron oxides, each having a single crystalline phase, during the catalytic cracking of a model coal compound, and found that the crystal structure was the key factor affecting the performance of the catalyst precursor. Kaneko et al. [20,21] assessed the physical properties and sulfidation activities of $\alpha-\mathrm{FeOOH}$, $\gamma$ - $\mathrm{FeOOH}$, ferrihydrite and two iron ores, and demonstrated that smaller pyrrhotite crystallite sizes correlate with higher oil yields. The particle size and extent of dispersion of the precursor are also important, and so ultrafine iron catalysts have been developed by numerous researchers $[13,22]$. Zhao et al. [23,24] has suggested that it is also important for the catalyst to maintain its dispersion at high temperatures, based on a comparative study of an ultrafine catalyst (with an average particle diameter of $3 \mathrm{~nm}$ ) and two binary iron oxide catalysts ( $\mathrm{Si} /$ ferrihydrite and $\mathrm{Al} /$ ferrihydrite, with average particle diameters of 5 and $10 \mathrm{~nm}$, respectively). Cugini [25] reported that liquefaction feed coal not only promoted the generation of ultrafine $\mathrm{FeOOH}$ but also assisted in dispersing the $\mathrm{Fe}_{1-x} \mathrm{~S}$ that was generated in situ during DCL. It is worth noting that ultrafine $\gamma$-FeOOH catalysts supported on coal have been successfully applied in the first megaton DCL industrial demonstration plant, operated by the Shenhua Group [26-28].

Many important results have been reported concerning the relationship between precursor catalyst properties and catalytic liquefaction activity, but these data have certain limitations because of variations in preparation methods as well as the compositions or sources of the catalyst precursors. In the present study, six unsupported iron-oxygen compounds having different microstructures were prepared by the same method and using the same raw materials, and the relationship between the microstructures of the catalyst precursors and their catalytic behaviors during coal liquefaction was systematically studied. In addition, a series of coal-supported catalyst precursors was prepared. The effects of the coal carrier and synthesis temperature on the formation of iron-oxygen compounds were assessed, with the aim of obtaining information of use during the future applications of industrial catalysts.

\section{Experimental}

\subsection{Coal and recycle solvent}

Table 2

The properties and ultimate analysis data for the recycle solvent.

\begin{tabular}{lccccccc}
\hline \multirow{2}{*}{$\rho^{20}\left(\mathrm{~g} / \mathrm{cm}^{3}\right)$} & \multirow{2}{*}{$f_{\mathrm{a}} \mathrm{a}$} & $\begin{array}{c}P D Q I^{\mathrm{b}} \\
(\mathrm{mg} / \mathrm{g})\end{array}$ & \multicolumn{5}{c}{$w(\mathrm{wt} \%)$} \\
\cline { 4 - 8 } & & $\mathrm{C}$ & $\mathrm{H}$ & $\mathrm{S}$ & $\mathrm{N}$ & $0^{\mathrm{c}}$ \\
\hline 0.9905 & 0.49 & 18.88 & 89.490 & 9.718 & 0.003 & 0.021 & 0.768
\end{tabular}

a Aromaticity $\left(f_{\mathrm{a}}\right)$ calculated from the ${ }^{1} \mathrm{H}$ NMR spectrum and elemental composition. b Proton donor quality (PDQI) calculated from the ${ }^{1} \mathrm{H}$ NMR spectrum and elemental composition. ${ }^{\mathrm{c}}$ Determined by difference.

The coal sample employed in experimental trials was obtained from the Shenhua Shangwan coal mine, which provides the feedstock for the Shenhua DCL demonstration plant. The coal was first ground to obtain particle sizes below $150 \mu \mathrm{m}$, dried under vacuum at $100{ }^{\circ} \mathrm{C}$ for $6 \mathrm{~h}$, and then stored in an airtight container. The results of the proximate, ultimate and petrographical analyses of the Shenhua Shangwan coal are shown in Table 1, while the properties of the recycle solvent produced by the demonstration plant are summarized in Table 2. The proton donor quality index (PDQI), as developed by Tanabe [29], reflects the hydrogen-donating ability of the solvent and is expressed in units of milliequivalents of $\beta$-naphthenic hydrogen per gram. The PDQI value of 18.88 $\mathrm{mg} / \mathrm{g}$ in Table 2 indicates superior hydrogen-donating ability. The aromaticity $\left(f_{\mathrm{a}}\right)$ value of the solvent $(0.49)$ was calculated based on its ${ }^{1} \mathrm{H}$ nuclear magnetic resonance (NMR) spectrum and elemental composition. These two parameters were calculated using the equations below $[4,29,30]$.

$$
\begin{gathered}
P D Q I=\frac{H_{\mathrm{N} \beta}}{H_{\mathrm{t}}} \times w(\mathrm{H}) \% \times 10 \\
f_{\mathrm{a}}=\left[\frac{w(\mathrm{C})}{w(\mathrm{H})}-\frac{H_{\mathrm{a}}}{2 H_{\mathrm{t}}}-\frac{H_{\beta}}{2 H_{\mathrm{t}}}-\frac{H_{\gamma}}{3 H_{\mathrm{t}}}\right] / \frac{w(\mathrm{C})}{w(\mathrm{H})}
\end{gathered}
$$

Here, $H_{\mathrm{N} \beta}, H_{\alpha}, H_{\gamma}, H_{\beta}$ and $H_{\mathrm{t}}$ are the intensities of the $\beta$-naphthenic hydrogen, $\alpha$-hydrogen, $\gamma$-hydrogen, $\beta$-hydrogen and total hydrogen peaks in the ${ }^{1} \mathrm{H}$ NMR spectrum, respectively, while $w(\mathrm{H})$ and $w(\mathrm{C})$ are the $\mathrm{H}$ and $\mathrm{C}$ mass concentrations in the recycle solvent, respectively.

\subsection{Preparation of catalyst precursors}

In a representative procedure, unsupported iron-oxygen compounds were synthesized by adding an ammonia solution (1.5 mol/L) dropwise to $500 \mathrm{~mL}$ of an aqueous ferrous sulfate solution $(0.3 \mathrm{~mol} / \mathrm{L})$ with vigorous stirring until the $\mathrm{pH}$ value reached $7.5 \pm 0.1$. Subsequently, the precipitate was obtained and oxidized by bubbling air $(600 \mathrm{~mL} / \mathrm{min})$ for $30 \mathrm{~min}$, maintaining the $\mathrm{pH}$ value at $7.5 \pm 0.1$ with an ammonia solution. The temperature of the reaction solution was controlled so as to remain constant during both the precipitation and oxidation processes. The resulting precipitate was separated by centrifugation at $5000 \mathrm{r} / \mathrm{min}$ for $10 \mathrm{~min}$ and then dried at $120^{\circ} \mathrm{C}$ under 
air for $24 \mathrm{~h}$. Finally, the iron-oxygen compounds were ground to a particle size of less than $80 \mu \mathrm{m}$ and stored under nitrogen in preparation for use. The unsupported iron-oxygen compounds synthesized at $20,30,40,50,60$ and $70{ }^{\circ} \mathrm{C}$ are denoted herein as Fe-20, Fe-30, Fe-40, Fe-50, Fe-60 and Fe-70, respectively.

The coal-supported iron-oxygen catalyst precursors were prepared in a similar manner to the unsupported materials, except that $150 \mathrm{~g}$ of the dried coal was first added to the 500 $\mathrm{mL} \mathrm{FeSO}_{4}$ solution to form a slurry prior to the precipitation. The coal-supported iron-oxygen compounds synthesized at 30, 45,60 and $75^{\circ} \mathrm{C}$ are denoted as Fe/C-30, Fe/C-45, Fe/C-60 and Fe/C-75, respectively.

\subsection{Characterization of iron-oxygen compounds}

The Fe concentrations in the unsupported iron-oxygen compounds were determined from the mass of ash after calcination at $900{ }^{\circ} \mathrm{C}$ for $3 \mathrm{~h}$. The Fe levels in the coal-supported iron-oxygen samples were obtained using an ultraviolet spectrophotometer (UNICO UV-2800A, USA). The samples were initially calcined at $900{ }^{\circ} \mathrm{C}$ for $3 \mathrm{~h}$, after which hydrochloric acid (37 wt $\%$ ) was added and then diluted by adding a mixture of ascorbic acid, acetic acid, sodium acetate and phenanthroline. The absorbance of the resulting solution at $510 \mathrm{~nm}$ was measured and compared to a standard calibration curve. The specific surface areas and pore volumes of the unsupported iron-oxygen compounds were obtained from $\mathrm{N}_{2}$ adsorption/desorption isotherms determined at liquid $\mathrm{N}_{2}$ temperature $\left(-196{ }^{\circ} \mathrm{C}\right)$ using an automatic analyzer (Micromeritics Tristar II 3020, USA). Prior to these adsorption measurements, each fresh sample (100 mg) was degassed under vacuum at $100{ }^{\circ} \mathrm{C}$ for $6 \mathrm{~h}$. The total pore volumes were calculated from the amount adsorbed at a relative pressure of 0.99 . The specific surface areas were calculated by the Brunauer-Emmett-Teller (BET) method and the total pore volumes were calculated via the Barrett-Joyner-Halenda (BJH) method. Powder X-ray diffraction (XRD) patterns of the samples were acquired with a D/max-RA X-ray diffractometer (Rigaku, Japan) using $\mathrm{Cu} K_{\alpha}$ radiation $(\lambda=0.154 \mathrm{~nm})$, operated at $40 \mathrm{kV}$ and $200 \mathrm{~mA}$. Standard powder XRD cards, compiled by the Joint Committee on Powder Diffraction Standards (JCPDS), were used to identify the iron phases of the precursors and sulfided catalysts. Scanning electron microscopy (SEM) images were obtained with S-4800 and S-4700 microscopes (Hitachi, Japan) operated at 5 and $15 \mathrm{kV}$, respectively. Thermogravimetric (TG) analysis was performed using a thermal analysis instrument (SDT-Q600, USA). During these trials, the mass loss was measured while applying a programmed $10^{\circ} \mathrm{C} / \mathrm{min}$ ramp to $200^{\circ} \mathrm{C}$, followed by a $4{ }^{\circ} \mathrm{C} / \mathrm{min}$ ramp to $300{ }^{\circ} \mathrm{C}$ and a $10{ }^{\circ} \mathrm{C} / \mathrm{min}$ ramp to $800{ }^{\circ} \mathrm{C}$ under nitrogen $(100 \mathrm{~mL} / \mathrm{min})$. Temperature-programmed reduction by $\mathrm{H}_{2}$ ( $\mathrm{H}_{2}$-TPR) experiments were performed using a chemisorption analyzer (Chembet PULSAR, Quantachrome, USA). Each sample (15 mg) was pretreated by calcination at $100{ }^{\circ} \mathrm{C}$ for $1 \mathrm{~h}$ and subsequently cooled to $50{ }^{\circ} \mathrm{C}$ under a He flow $(30 \mathrm{~mL} / \mathrm{min})$. Thereafter, the catalyst bed was subjected to a $5 \% \mathrm{H}_{2}-95 \%$ Ar flow ( $30 \mathrm{~mL} / \mathrm{min}$ ) at $50{ }^{\circ} \mathrm{C}$ for $20 \mathrm{~min}$, fol- lowed by heating at a rate of $10^{\circ} \mathrm{C} / \mathrm{min}$ up to $900{ }^{\circ} \mathrm{C}$. Finally, the reduction sample was cooled under a He flow $(30 \mathrm{~mL} / \mathrm{min})$. The $\mathrm{H}_{2}$ consumption as a function of the reduction temperature was continuously monitored using a thermal conductivity detector (TCD).

\subsection{Sulfidation of unsupported iron-oxygen compounds}

Sulfidation of the unsupported iron-oxygen compounds was conducted with a $0.5 \mathrm{~L}$ autoclave (Parr4575, USA). During sulfidation, a quantity of the unsupported iron-oxygen compound (containing $0.42 \mathrm{~g} \mathrm{Fe}$ ) was combined with $0.48 \mathrm{~g}$ of sulfur as a sulfidation agent (at a S/Fe molar ratio of 2) and $60 \mathrm{~g}$ of recycle solvent in the autoclave. The autoclave was subsequently flushed with hydrogen three times and then pressurized with hydrogen to $10.0 \mathrm{MPa}$ at room temperature. The autoclave was heated to $300{ }^{\circ} \mathrm{C}$ at a rate of $20{ }^{\circ} \mathrm{C} / \mathrm{min}$ in conjunction with stirring of the reaction solution at $500 \mathrm{r} / \mathrm{min}$. At the point at which the reaction solution temperature reached $300{ }^{\circ} \mathrm{C}$, or after holding at $300{ }^{\circ} \mathrm{C}$ for $1 \mathrm{~h}$, the autoclave was cooled rapidly to room temperature using a high-powered blower. The sulfided catalyst was washed with tetrahydrofuran (THF), followed by filtration and vacuum drying at $80{ }^{\circ} \mathrm{C}$ for $4 \mathrm{~h}$ to remove the THF, after which the catalyst was stored under nitrogen.

XRD and SEM were used to characterize the sulfided catalyst, and the average crystallite size of the $\mathrm{Fe}_{1-x} \mathrm{~S}$ was calculated via the Scherrer equation based on the full width at half-maximum of the (200) XRD peaks. The samples heated at $300{ }^{\circ} \mathrm{C}$ for $0 \mathrm{~h}$ and for $1 \mathrm{~h}$ are denoted herein as Fe- $x$-S/0 and $\mathrm{Fe}-\mathrm{x}$-S/1, respectively (where $x$ represents the synthesis temperature).

\subsection{Catalytic coal liquefaction tests}

Catalytic hydroliquefaction trials using the Shenhua Shangwan coal were performed in a $0.5 \mathrm{~L}$ autoclave reactor (Parr4575, USA). In the case of the unsupported catalyst, $28.0 \mathrm{~g}$ of dry coal, $42.0 \mathrm{~g}$ of recycle solvent, $0.32 \mathrm{~g}$ of elemental sulfur (such that the $\mathrm{S} /$ catalyst atomic ratio was $2 / 1$ ) and a quantity of the catalyst (containing $0.28 \mathrm{~g} \mathrm{Fe}$, such that the Fe/coal mass ratio was $1 / 100$, based on the Fe concentrations in Table 3) were added to the autoclave. In the case of the coal-supported catalysts, the amounts of recycle solvent and sulfur were the same, as was the Fe/coal ratio, while the amount of added coal was $28.0 \mathrm{~g}$ minus the mass of coal in the coal-supported catalyst. The Fe and coal concentrations in the coal-supported catalysts are provided in Table 3. After being flushed three times with hydrogen, the autoclave was pressurized with hydrogen to $10.0 \mathrm{MPa}$ at room temperature then heated to $450{ }^{\circ} \mathrm{C}$ at a rate of $20^{\circ} \mathrm{C} / \mathrm{min}$ with stirring at $500 \mathrm{r} / \mathrm{min}$. After holding at $450{ }^{\circ} \mathrm{C}$ for $1.0 \mathrm{~h}$, the autoclave was cooled rapidly to room temperature using a high-powered blower. The gaseous reaction products were analyzed using a gas chromatograph (Agilent 7890A), with the hydrocarbons detected with a flame ionization detector in conjunction with an $\mathrm{Al}_{2} \mathrm{O}_{3}$ capillary column, and the $\mathrm{N}_{2}, \mathrm{CO}, \mathrm{CO}_{2}, \mathrm{H}_{2}$ and $\mathrm{H}_{2} \mathrm{~S}$ detected with a TCD, using 
Table 3

The compositions of the catalysts and the results of coal liquefaction.

\begin{tabular}{|c|c|c|c|c|c|c|c|c|}
\hline \multirow{2}{*}{ Catalyst } & \multirow{2}{*}{$\begin{array}{c}\text { Fe content } \\
(\mathrm{wt} \%)\end{array}$} & \multirow{2}{*}{$\begin{array}{c}\text { Coal content } \\
(w \mathrm{t} \%)\end{array}$} & \multirow{2}{*}{$\begin{array}{l}\text { Conversion } \\
\text { (wt } \%)\end{array}$} & \multirow{2}{*}{$\begin{array}{c}\mathrm{H}_{2} \text { consumption } \\
(\mathrm{wt} \%)\end{array}$} & \multicolumn{4}{|c|}{ Yield (wt\%) } \\
\hline & & & & & Gas & $\mathrm{H}_{2} \mathrm{O}$ & PAA & Oil \\
\hline Fe-20 & 61.5 & - & 87.9 & 4.0 & 14.5 & 12.5 & 9.7 & 55.2 \\
\hline $\mathrm{Fe}-30$ & 61.6 & - & 87.7 & 4.1 & 14.2 & 12.4 & 9.9 & 55.3 \\
\hline $\mathrm{Fe}-40$ & 62.1 & - & 86.6 & 4.0 & 14.2 & 12.5 & 9.2 & 54.7 \\
\hline $\mathrm{Fe}-50$ & 66.4 & - & 86.5 & 4.0 & 14.3 & 12.6 & 9.5 & 54.2 \\
\hline Fe-60 & 68.3 & - & 86.0 & 4.0 & 14.6 & 12.5 & 10.4 & 52.5 \\
\hline $\mathrm{Fe}-70$ & 68.2 & - & 84.9 & 3.6 & 14.1 & 12.5 & 11.3 & 50.6 \\
\hline $\mathrm{Fe} / \mathrm{C}-30$ & 5.0 & 91.1 & 88.7 & 4.4 & 14.5 & 12.6 & 8.6 & 57.4 \\
\hline $\mathrm{Fe} / \mathrm{C}-45$ & 5.1 & 90.9 & 88.5 & 4.3 & 14.5 & 12.6 & 8.5 & 57.2 \\
\hline $\mathrm{Fe} / \mathrm{C}-60$ & 5.1 & 91.7 & 87.5 & 4.2 & 14.6 & 12.6 & 9.1 & 55.4 \\
\hline $\mathrm{Fe} / \mathrm{C}-75$ & 5.2 & 91.6 & 87.7 & 4.2 & 14.7 & 12.4 & 10.8 & 54.0 \\
\hline
\end{tabular}

a 13X molecular sieve packed column. All liquid and solid products were recovered via sequential Soxhlet extraction with hexane and THF over $48 \mathrm{~h}$. The hexane-soluble substances were defined as oils, while the hexane-insoluble, THF-soluble substances were defined as preasphaltene and asphaltene. Ash values were obtained by calcination of the THF-insoluble substances at $815^{\circ} \mathrm{C}$ for $6 \mathrm{~h}$ in a muffle furnace. The coal conversion $(X)$, oil yield $(O)$, gas yield $(G)$, preasphaltene and asphaltene yield $(P A A)$, hydrogen consumption $(H)$ and water yield $(W)$ were calculated on a dry, ash-free (daf) basis using the following equations.

$$
\begin{gathered}
X=1-(T I-A s h) / F_{\mathrm{daf}} \\
P A A=(H I-T I) / F_{\mathrm{daf}} \\
H=\left(H_{0}-H_{1}\right) / F_{\mathrm{daf}} \\
G=\left(G_{1}-H_{1}\right) / F_{\mathrm{daf}} \\
W=1.125\left(O_{0}-O_{1}-O_{2}\right) / F_{\mathrm{daf}} \\
O=X+H-G-W-P A A
\end{gathered}
$$

Here, $F_{\text {daf }}$ is the mass of coal on a moisture-free and daf basis (g), $H_{0}$ is the mass of hydrogen added to the reactor $(\mathrm{g}), H_{1}$ is the mass of hydrogen recovered after the reaction (g), $G_{1}$ is the mass of gaseous products $(\mathrm{g}), \mathrm{HI}$ is the mass of hexane-insoluble substances (g), TI is the mass of THF-insoluble substances (g), Ash is the mass of ash (g), $O_{0}$ is the mass of elemental oxygen in the feed coal ( $\mathrm{g}), O_{1}$ is the mass of elemental oxygen in the gaseous products $(\mathrm{g})$, and $\mathrm{O}_{2}$ is the mass of elemental oxygen in the liquid and solid products (estimated to be $10.73 \%$ of the elemental oxygen in the feed coal [31], g).

It was assumed that the total mass of ash was equal to that of the THF-insoluble substances. The coal liquefaction data reported herein represent the average of three replicate trials, during which the relative deviations in the conversion and oil yield values were found to be within $0.5 \%$ and $1 \%$, respectively.

\section{Results and discussion}

\subsection{Catalytic activities of unsupported and coal-supported iron-oxygen compounds during coal liquefaction}

The results obtained from catalytic coal liquefaction using unsupported and coal-supported iron-oxygen compounds are shown in Table 3. It can be seen that the catalyst precursors synthesized at lower temperatures exhibited better catalytic activity, such that the Fe-20 and Fe-30 gave the highest coal conversion and oil yield. The oil yield from the Fe-70 was decreased by $4.6 \%$ compared to that of the $\mathrm{Fe}-20$, along with $0.4 \%$ lower hydrogen consumption and a $1.6 \%$ increase in asphalt yield. Among the coal-supported iron-oxygen compounds, the Fe/C-30 exhibited the highest coal conversion and oil yield, with values of $88.7 \%$ and $57.4 \%$, respectively. The oil yield from the Fe/C-45 was slightly decreased (by $0.2 \%$ ), while those obtained from the Fe/C-60 and Fe/C-75 were much lower.

\subsection{Properties of the unsupported iron-oxygen compounds}

SEM micrographs of the unsupported iron-oxygen compounds are presented in Fig. 1. The Fe-20 and Fe-30 particles were evidently rod-like or needle-like in shape, while a few spherical-like particles appeared in the Fe-40. These spherical particles became more common as the synthesis temperature was increased to $70^{\circ} \mathrm{C}$, along with increases in the particle size (from 80-100 to 100-300 nm). These changes in morphology indicate that the growth rates of the crystal faces were affected by the synthesis temperature differently, and that the growth of the iron-oxygen crystals was primarily determined by thermodynamics.

A gradual transformation in the crystalline phase of the unsupported iron-oxygen compounds with increases in the synthesis temperature can be seen in Fig. 2. Initially, $\gamma$-FeOOH peaks are generated by the Fe-20, while the intensity of these peaks gradually weakens in the case of the Fe-30 and Fe-40. In addition, $\alpha-\mathrm{FeOOH}$ peaks are first observed in the Fe-30 pattern, become more prominent in the $\mathrm{Fe}-40$ pattern, then weaken and finally vanish in the Fe-50 and Fe-60 patterns. In addition, $\gamma-\mathrm{Fe}_{2} \mathrm{O}_{3}$ peaks were first generated by the $\mathrm{Fe}-40$ and are more intense in the $\mathrm{Fe}-60$ and $\mathrm{Fe}-70$ patterns. The variations in the crystalline phases of these iron-oxygen compounds suggest that the synthesis temperature had an impact on the iron-oxide coordination and the connecting structural units in these materials. Lower temperatures were conducive to the formation of hydrogen bonds in $\gamma-\mathrm{FeOOH}$, while moderate temperatures promoted the formation of $\alpha-\mathrm{FeOOH}$ structures with regular channels, and higher temperatures favored the appearance of a cubic $\gamma-\mathrm{Fe}_{2} \mathrm{O}_{3}$ structure [32].

Fig. 3 presents the results of TG analyses of the unsupported 

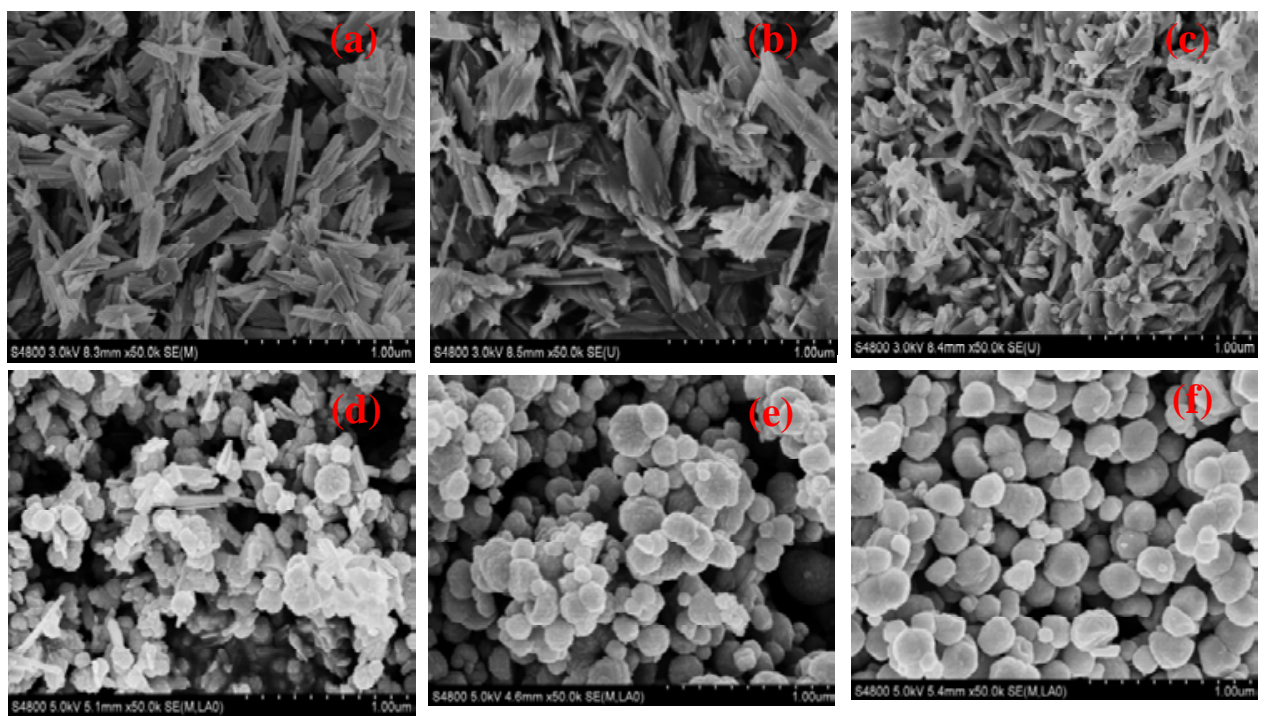

Fig. 1. SEM images of the unsupported iron-oxygen compounds. (a) Fe-20; (b) Fe-30; (c) Fe-40; (d) Fe-50; (e) Fe-60; (f) Fe-70.

iron-oxygen compounds. An obvious mass loss can be seen from $150-300{ }^{\circ} \mathrm{C}$ in each case, attributed to the conversion of $\mathrm{FeOOH}$ to $\mathrm{Fe}_{2} \mathrm{O}_{3}$. The $\mathrm{Fe}-20$ and $\mathrm{Fe}-30$ both had mass loss val-

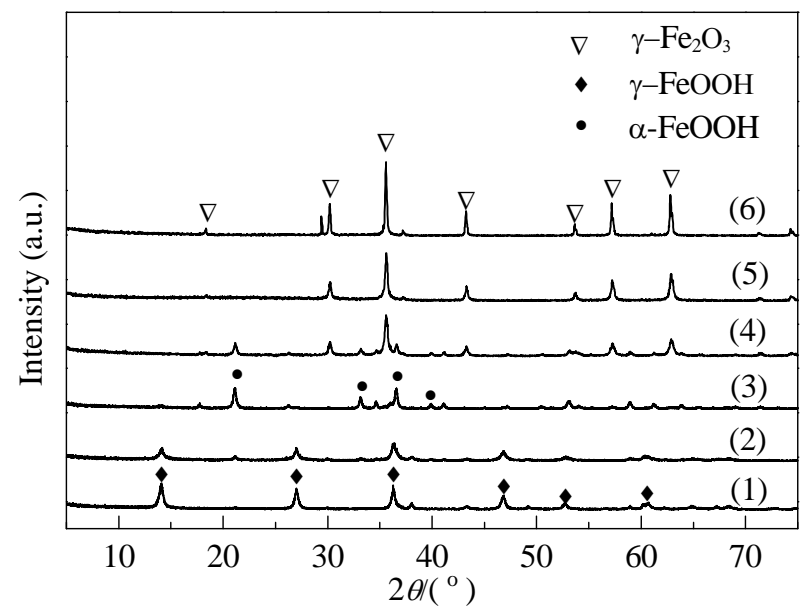

Fig. 2. XRD patterns of the unsupported iron-oxygen compounds. (1) Fe-20; (2) Fe-30; (3) Fe-40; (4) Fe-50; (5) Fe-60; (6) Fe-70.

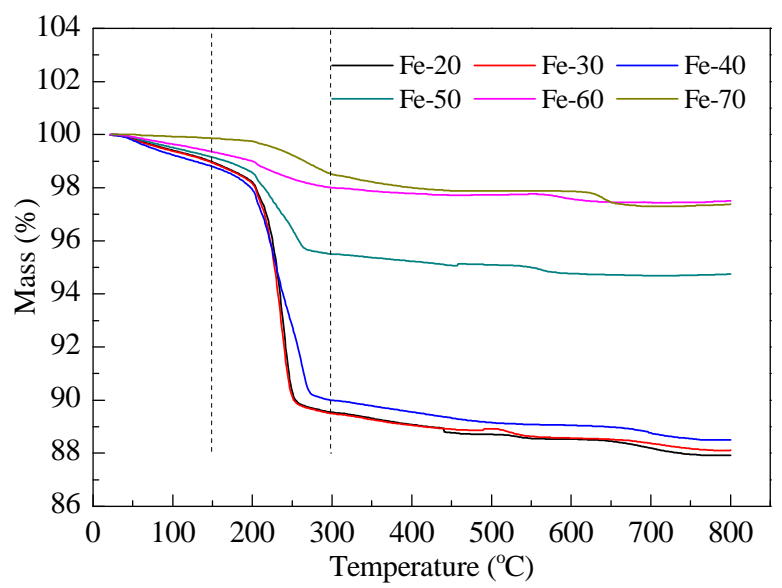

Fig. 3. TG profiles of the unsupported iron-oxygen compounds. ues of $9.4 \%$ in this region (Table 4), which is close to the theoretical value expected for the decomposition of $\mathrm{FeOOH}$ to $\mathrm{Fe}_{2} \mathrm{O}_{3}$ (10.11\%). In contrast, the Fe-60 and Fe-70 showed values of less than $1.4 \%$. The decreased mass loss of these compounds indicates a lower $\mathrm{FeOOH}$ content with increases in the synthesis temperature, in accordance with the XRD results.

Moisture content is thought to be an important factor that should be controlled when attempting to improve the catalytic activity of iron oxide powders [19], and has been used as a standard for selecting limonite catalysts for coal liquefaction [33]. The oil yields in the present work are plotted as a function of the unsupported iron-oxygen compound moisture contents in Fig. 4. These data demonstrate that a high moisture level improves the oil yield. In this study, the moisture content was correlated with the proportion of the $\mathrm{FeOOH}$ phase in the precursors, suggesting that the higher catalytic activity can actually be attributed to a greater amount of $\mathrm{FeOOH}$. However, it was not possible to confirm whether the $\gamma$-FeOOH or $\alpha$-FeOOH precursors had a stronger effect on the oil yield.

The BET data acquired from the unsupported iron-oxygen compounds are shown in Table 4, where it is evident that increases in the synthesis temperature decrease both the surface area and pore volume. The Fe-20 had the largest surface area of $72.3 \mathrm{~m}^{2} / \mathrm{g}$ and pore volume of $0.30 \mathrm{~mL} / \mathrm{g}$, while the surface areas of the Fe-60 and Fe-70 were only 3.8 and $1.5 \mathrm{~m}^{2} / \mathrm{g}$, respectively, along with significantly decreased pore volumes.

Table 4

TG and BET results for the unsupported iron-oxygen compounds.

\begin{tabular}{lcccc}
\hline \multirow{2}{*}{ Catalyst } & \multicolumn{2}{c}{ TG } & $\begin{array}{c}\text { BET specific } \\
\text { surface area } \\
\left(\mathrm{m}^{2} / \mathrm{g}\right)\end{array}$ & $\begin{array}{c}\text { Total pore } \\
\text { volume } \\
(\mathrm{mL} / \mathrm{g})\end{array}$ \\
\cline { 2 - 5 } & $\begin{array}{c}\text { Total weight } \\
\text { loss (wt\%) }\end{array}$ & $\begin{array}{c}\text { Weight loss in } \\
150-300^{\circ} \mathrm{C}(\mathrm{wt} \%)\end{array}$ \\
\hline $\mathrm{Fe}-20$ & 12.1 & 9.4 & 72.3 & 0.30 \\
$\mathrm{Fe}-30$ & 11.9 & 9.4 & 56.9 & 0.22 \\
$\mathrm{Fe}-40$ & 11.5 & 8.8 & 33.3 & 0.14 \\
$\mathrm{Fe}-50$ & 5.3 & 3.6 & 11.6 & 0.04 \\
$\mathrm{Fe}-60$ & 2.5 & 1.4 & 3.8 & 0.01 \\
$\mathrm{Fe}-70$ & 2.6 & 1.3 & 1.5 & - \\
\hline
\end{tabular}




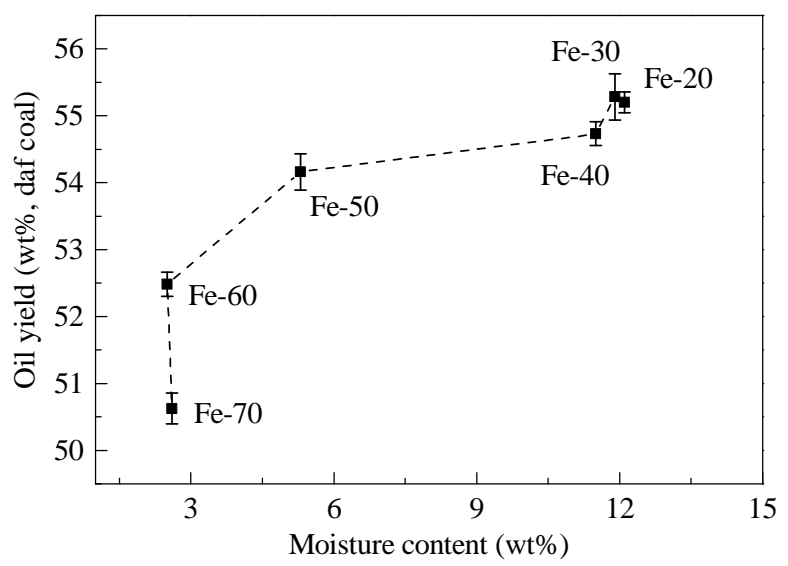

Fig. 4. The oil yield as a function of moisture content as determined by TG analysis of unsupported iron-oxygen compounds.

Increasing the synthesis temperature thus may reduce the surface area and pore volume and limit the transformation of the precursors to the active phase during coal liquefaction. Fig. 5 presents a plot of the oil yield as a function of the surface areas of the iron-oxygen precursors. A general trend is apparent in which higher surface area precursors produce higher oil yields. However, the initial rapid rise of this plot and subsequent plateau suggest that the initial surface area of the iron-oxygen compound precursor is not the only factor affecting the catalytic activity.

Information regarding the relative difficulty in transforming the precursor to the active phase can be obtained from $\mathrm{H}_{2}$-TPR. Each of the unsupported iron-oxygen compounds show two hydrogen consumption peaks in Fig. 6. The peaks in the low temperature region $\left(300\right.$ to $450{ }^{\circ} \mathrm{C}$ ) correspond to the reduction of $\mathrm{Fe}_{2} \mathrm{O}_{3}$ to $\mathrm{Fe}_{3} \mathrm{O}_{4}$, while peaks in the high temperature region $\left(450\right.$ to $\left.800{ }^{\circ} \mathrm{C}\right)$ are due to the reduction of $\mathrm{Fe}_{3} \mathrm{O}_{4}$ to $\mathrm{FeO}$ and $\mathrm{FeO}$ to $\mathrm{Fe}$ [34]. A slight shift of the low temperature peaks to higher temperatures is evident (Fig. 6, arrow B), indicating that increases in the synthesis temperature impede the reduction of $\mathrm{Fe}_{2} \mathrm{O}_{3}$ to $\mathrm{Fe}_{3} \mathrm{O}_{4}$. In addition, the small shoulder peaks (Fig. 6, arrow A) associated with the reduction of fine crystallites of $\mathrm{Fe}_{2} \mathrm{O}_{3}$ to $\mathrm{Fe}_{3} \mathrm{O}_{4}$ are also shifted to higher temperatures.

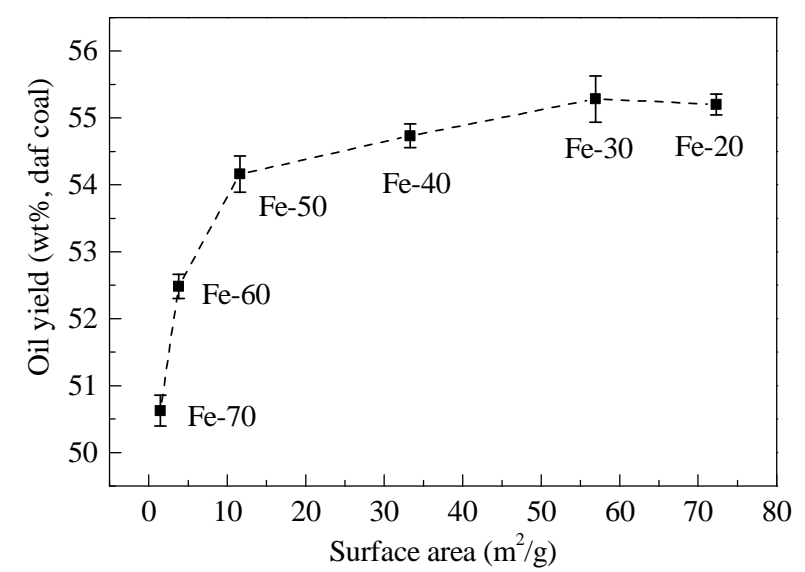

Fig. 5. Oil yield as a function of surface area for the unsupported iron-oxygen compounds.

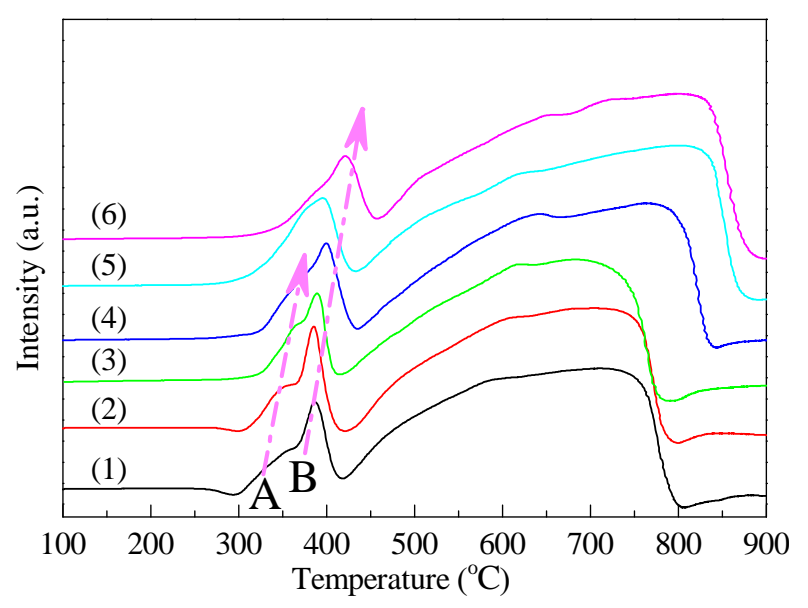

Fig. 6. $\mathrm{H}_{2}$-TPR profiles of the unsupported iron-oxygen compounds. (1) Fe-20; (2) Fe-30; (3) Fe-40; (4) Fe-50; (5) Fe-60; (6) Fe-70.

This result demonstrates that there were fewer fine $\mathrm{Fe}_{2} \mathrm{O}_{3}$ crystallites in the precursors made at higher temperatures. The difficulty in reducing $\mathrm{Fe}_{2} \mathrm{O}_{3}$ to $\mathrm{Fe}_{3} \mathrm{O}_{4}$ noted above would lower both the quantity and activity of active oxygen species in the iron-oxygen compounds, implying a more difficult transformation to the active phase (pyrrhotite) during coal liquefaction.

\subsection{Properties of sulfided catalysts}

Sulfidation is an important step for the transformation of iron-containing precursors into $\mathrm{Fe}_{1-\mathrm{x}} \mathrm{S}$, which acts as the active phase during coal liquefaction. As shown in Fig. 7, the morphologies of the sulfide generated in this work were similar to the morphologies of their precursors, but the manner by which each precursor was transitioned to the active phase was different. The rod- or needle-like $\mathrm{FeOOH}$ particles in catalysts synthesized at 20 to $40{ }^{\circ} \mathrm{C}$ were found to shrink or fracture to give small, thin hexagonal $\mathrm{Fe}_{1-x} \mathrm{~S}$ particles. In contrast, the spherical precursors made at 50 to $70{ }^{\circ} \mathrm{C}$ tended to transform directly into regular sheets of $\mathrm{Fe}_{1-x} \mathrm{~S}$.

As shown in Fig. 8, each of the precursors was transformed into $\mathrm{Fe}_{1-\mathrm{x}} \mathrm{S}$ after sulfidation at $300{ }^{\circ} \mathrm{C}$ for either 0 or $1 \mathrm{~h}$. The peak at $2 \theta=26^{\circ}$ indicates the presence of graphite (PDF \#89-8487) due to a carbon deposition reaction involving the solvent, with graphite deposited on the catalyst surfaces. The average crystallite sizes of the $\mathrm{Fe}_{1-x} \mathrm{~S}$ were calculated using the Scherrer formula, and the $(1-x)$ mean values were determined using an empirical formula developed by Djega-Mariadassou and Lambert et al. [35,36]. The results are shown in Table 5.

The Fe-20-S/0, Fe-30-S/0 and Fe-40-S/0 had similar crystallite sizes and $(1-x)$ value (crystallite sizes from 14.1-14.4 $\mathrm{nm},(1-x)$ values from $0.855-0.860$ ), but there were obvious increases in these parameters for the Fe-50-S/0, Fe-60-S/0 and Fe-70-S/0. It was also found that the crystallite sizes and (1- $x$ ) values of the sulfided catalysts increased slightly following sulfidation at $300{ }^{\circ} \mathrm{C}$ for $1 \mathrm{~h}$. The crystallite size trend was similar to that exhibited by the $(1-x)$ values, indicating a decrease in the coordination number of sulfur in the pyrrhotite with the 

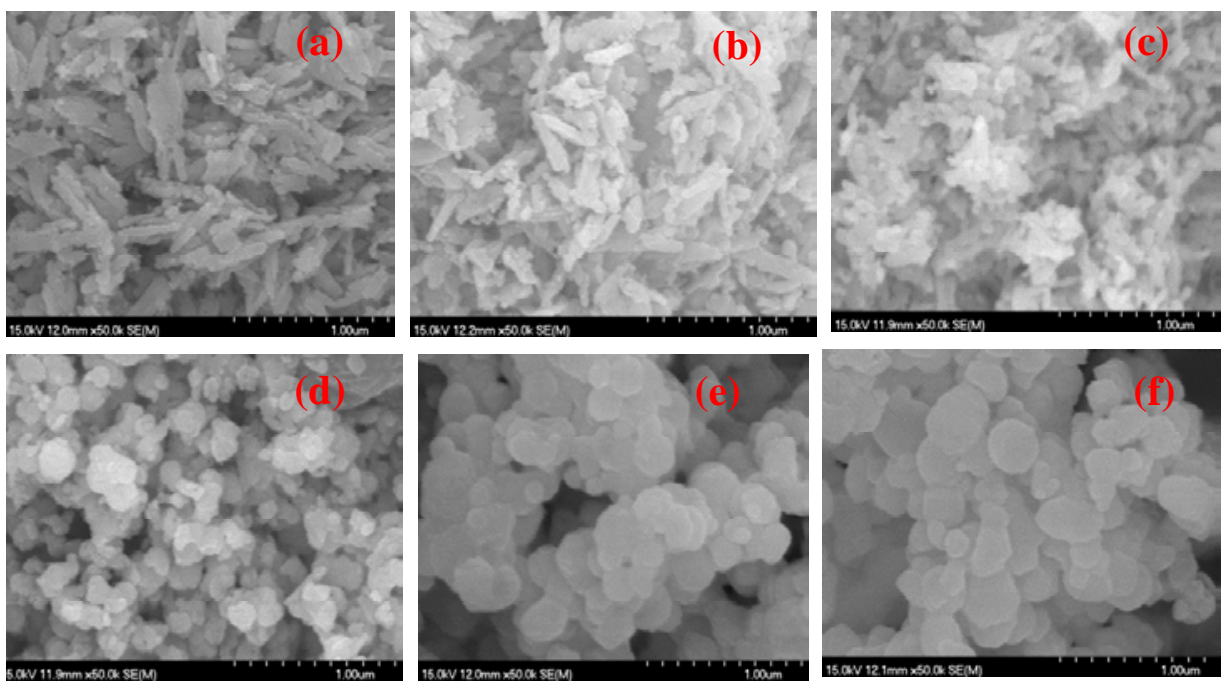

Fig. 7. SEM images of unsupported iron-oxygen compounds after sulfidation at $300{ }^{\circ} \mathrm{C}$ with a $0 \mathrm{~h}$ hold time. (a) Fe-20-S/0; (b) Fe-30-S/0; (c) Fe-40-S/0; (d) Fe-50-S/0; (e) Fe-60-S/0; (f) Fe-70-S/0.
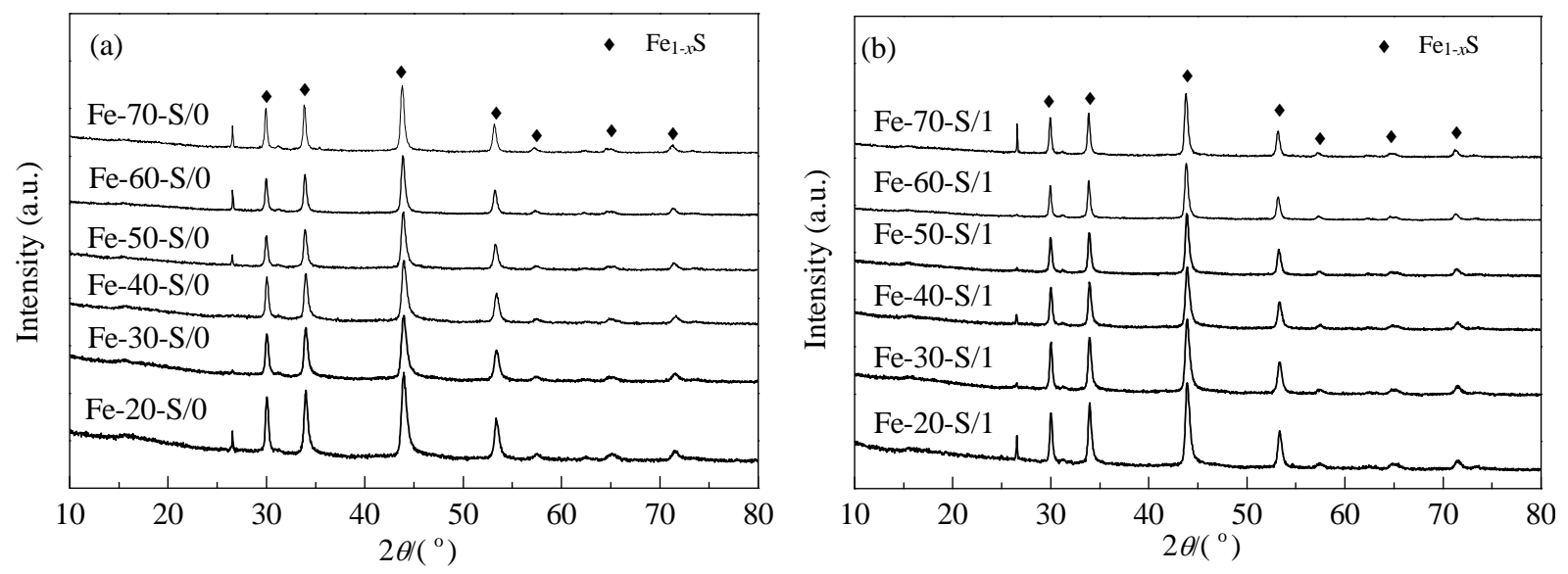

Fig. 8. XRD patterns of unsupported iron-oxygen compounds after sulfidation at $300^{\circ} \mathrm{C}$ with 0 (a) and 1 (b) h hold times.

crystallite size growth. An approximately linear correlation between the oil yield and the pyrrhotite crystallite size can be seen in Fig. 9, suggesting that smaller crystallites are associated with higher oil yields. The crystallite size of the pyrrhotite could therefore be one of the main parameters determining the activity of the catalyst.

\section{Table 5}

Calculated $(1-x)$ values and crystallite sizes of the sulfidation catalysts.

\begin{tabular}{lccccc}
\hline Catalyst & $\begin{array}{c}\text { Crystallite } \\
\text { size }^{a}(\mathrm{~nm})\end{array}$ & $\begin{array}{c}\text { Iron } \\
\text { sulfide }\end{array}$ & Catalyst & $\begin{array}{c}\text { Crystallite } \\
\text { size }^{\mathrm{a}}(\mathrm{nm})\end{array}$ & $\begin{array}{c}\text { Iron } \\
\text { sulfide }\end{array}$ \\
\hline $\mathrm{Fe}-20-\mathrm{S} / 0$ & 14.1 & $\mathrm{Fe}_{0.860} \mathrm{~S}$ & $\mathrm{Fe}-20-\mathrm{S} / 1$ & 17.4 & $\mathrm{Fe}_{0.869} \mathrm{~S}$ \\
$\mathrm{Fe}-30-\mathrm{S} / 0$ & 14.2 & $\mathrm{Fe}_{0.858} \mathrm{~S}$ & $\mathrm{Fe}-30-\mathrm{S} / 1$ & 17.1 & $\mathrm{Fe}_{0.867} \mathrm{~S}$ \\
$\mathrm{Fe}-40-\mathrm{S} / 0$ & 14.4 & $\mathrm{Fe}_{0.855} \mathrm{~S}$ & $\mathrm{Fe}-40-\mathrm{S} / 1$ & 17.9 & $\mathrm{Fe}_{0.869} \mathrm{~S}$ \\
$\mathrm{Fe}-50-\mathrm{S} / 0$ & 16.5 & $\mathrm{Fe}_{0.867} \mathrm{~S}$ & $\mathrm{Fe}-50-\mathrm{S} / 1$ & 22.1 & $\mathrm{Fe}_{0.877} \mathrm{~S}$ \\
$\mathrm{Fe}-60-\mathrm{S} / 0$ & 20.9 & $\mathrm{Fe}_{0.878} \mathrm{~S}$ & $\mathrm{Fe}-60-\mathrm{S} / 1$ & 24.0 & $\mathrm{Fe}_{0.888} \mathrm{~S}$ \\
$\mathrm{Fe}-70-\mathrm{S} / 0$ & 21.4 & $\mathrm{Fe}_{0.888} \mathrm{~S}$ & $\mathrm{Fe}-70-\mathrm{S} / 1$ & 24.7 & $\mathrm{Fe}_{0.892} \mathrm{~S}$ \\
\hline
\end{tabular}

a The average $\mathrm{Fe}_{1-x} \mathrm{~S}$ crystallite size as calculated with the Scherrer equation from the full width at half-maximum values of (200) XRD peaks.

${ }^{\mathrm{b}} \mathrm{Fe}(\%)=45.212+72.86\left(d_{202}-2.0400\right)+311.5\left(d_{202}-2.0400\right)^{2}$, where Fe (\%) is the atomic percent of iron in $\mathrm{Fe}_{1-x} S$ and $d_{202}$ is the $d$ spacing $(\AA)$ of the (202) XRD peak of $\mathrm{Fe}_{1-x} \mathrm{~S}$.

\subsection{Properties of coal-supported iron-oxygen compounds}

The micrographs of the coal-supported iron-oxygen compounds are shown in Fig. 10. The iron-oxygen compounds synthesized at different temperatures were well dispersed on

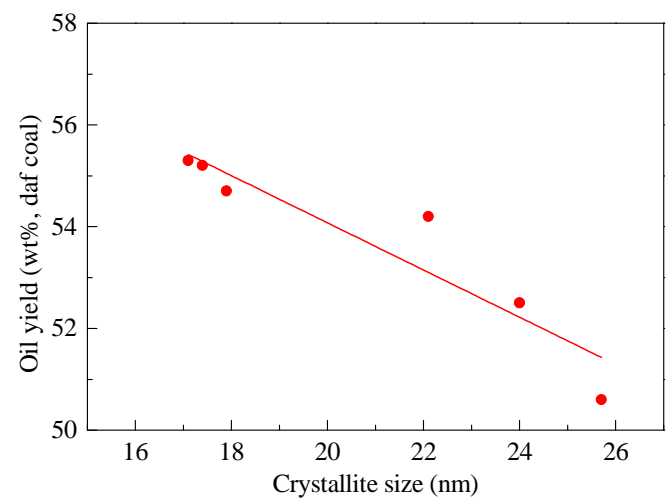

Fig. 9. The oil yield as a function of the pyrrhotite crystallite size, employing samples sulfided at $300^{\circ} \mathrm{C}$ for $1 \mathrm{~h}$. 


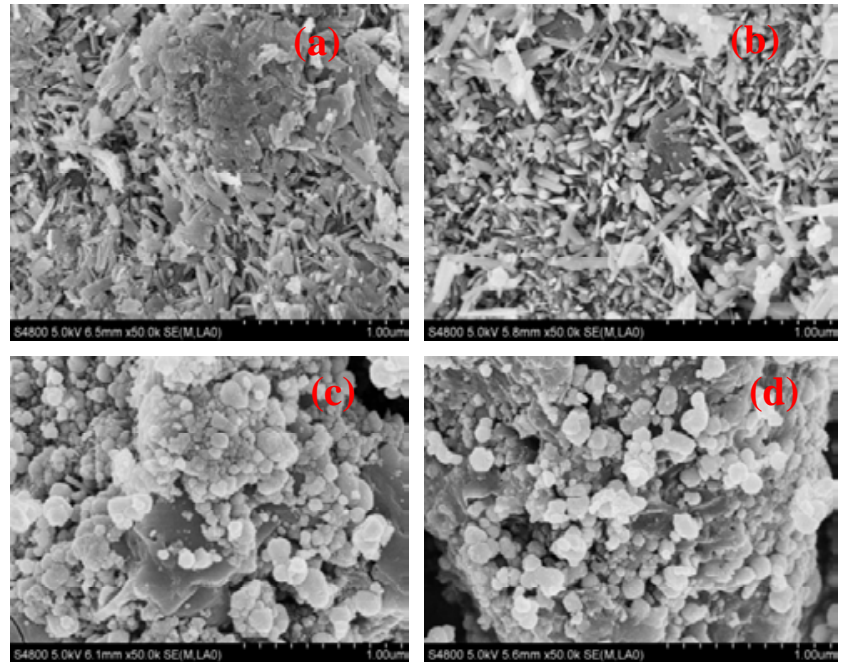

Fig. 10. SEM images of the coal-supported iron-oxygen compounds. (a) Fe/C-30; (b) Fe/C-45; (c) Fe/C-60; (d) Fe/C-75.

the surface of the carrier coal, and these compounds were similar to the unsupported catalysts in morphology. Moreover, the particle sizes of the iron-oxygen compounds on the coal were much smaller than those of the unsupported catalysts. The carrier coal played a role by inhibiting secondary polymerization of precipitated grains in the synthesis process. Although the carrier coal decreased the particle size and improved the dispersion of the iron-oxygen compounds, some aggregation still occurred. This suggests that the process should be further optimized. Fig. 11 shows XRD patterns acquired from the coal supported iron-oxygen compounds. The effects of synthesis temperature on the crystalline phases were similar to those observed with the unsupported materials, indicating a lack of obvious chemical interactions between the carrier coal and the precursors.

Although the addition of a coal support did not significantly affect the crystal structure and morphology of the iron-oxygen compound precursors, the catalytic activities of the coal-supported iron-oxygen compounds were superior to

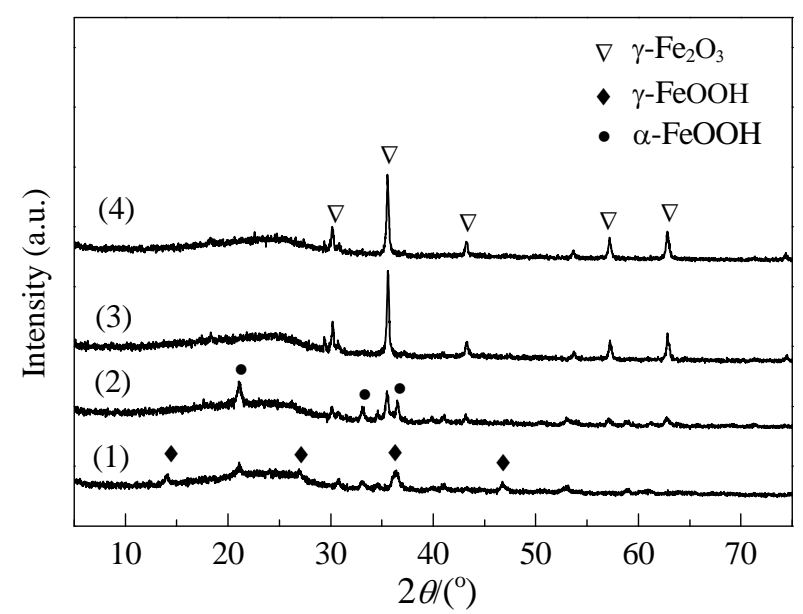

Fig. 11. XRD patterns of the coal-supported iron-oxygen compounds. (1) Fe/C-30, (2) Fe/C-45, (3) Fe/C-60; (4) Fe/C-75. those of the unsupported materials synthesized at similar temperatures, because of the smaller particle sizes. In addition to improving the dispersion of the precursors, the carrier coal could potentially inhibit aggregation of the $\mathrm{Fe}_{1-x} \mathrm{~S}$ during coal liquefaction.

\section{Conclusions}

The performance of the catalyst during DCL is the result of many factors, and so it is difficult to identify a single parameter that directly correlates with the catalytic activity or oil yield. In this work, unsupported iron-oxygen compound precursors synthesized at lower temperatures and composed primarily of $\gamma$-FeOOH or $\alpha$-FeOOH crystalline phases, also having high specific surface areas, elevated moisture levels and more active oxygen, readily transformed to fine pyrrhotite. These materials also exhibited superior catalytic activity during DCL. The type of pyrrhotite obtained was found to be closely related to the properties of the precursors, and an approximately linear correlation was established between the oil yield and the pyrrhotite crystallite size. The crystalline phase may be the most important attribute of the iron-oxygen compound precursors because this factor is closely associated with other important attributes, such as the texture, morphology and particle size of the precursor.

When used as a carrier for the catalyst, liquefaction coal does not modify the crystalline phase or morphology, but can improve the catalytic activity significantly. The carrier coal appears to effectively inhibit secondary polymerization and particle size changes of the iron-oxygen compounds. Both the particle size and the dispersion of the precursor are equally important to the formation of a crystalline phase. Therefore, using liquefaction feed coal as a carrier for the catalyst is a facile and effective means of improving catalytic performance during coal liquefaction.

\section{References}

[1] I. Mochida, O. Okuma, S. H. Yoon, Chem. Rev., 2014, 114, 1637-1672.

[2] Z. Y. Liu, S. D. Shi, Y. W. Li, Chem. Eng. Sci., 2010, 65, 12-17.

[3] M. X. Zhao, X. Y. Wei, Z. M. Zong, Chin. J. Catal., 2016, 37, 1324-1330.

[4] S. S. Gao, D. X. Zhang, K. J. Li, Energies, 2015, 8, 6795-6805.

[5] S. Vasireddy, B. Morreale, A. Cugini, C. Song, J. J. Spivey, Energy Environ. Sci., 2010, 4, 311-345.

[6] J. Xie, H. F. Lu, Y. C. Chen, S. S. Gao, H. X. Wang, CIESC J., 2016, 67, 1892-1899.

[7] Y. Z. Li, F. Y. Ma, X. T. Su, L. J. Shi, B. B. Pan, Z. Q. Sun, Y. L. Hou, Ind. Eng. Chem. Res., 2014, 53, 6718-6722.

[8] J. H. Guo, J. L. Yang, Z. Y. Liu, Chin. J. Catal., 2000, 21, 165-168.

[9] X. Li, S. X. Hu, L. J. Jin, H. Q. Hu, Energy Fuels, 2008, 22, 1126-1129.

[10] F. V. Stohl, K. V. Diegert, Energy Fuels, 1994, 8, 117-123.

[11] Y. Z. Li, F. Y. Ma, X. T. Su, C. Sun, J. C. Liu, Z. Q. Sun, Y. L. Hou, Catal. Commun., 2012, 26, 231-234.

[12] L. J. Jin, K. M. Han, J. Y. Wang, H. Q. Hu, Fuel Process Technol., 2014, 128, 232-237.

[13] A. V. Cugini, D. Krastman, R. G Lett, V. D. Balsone, Catal. Today, 1994, 19, 395-407. 


\title{
Graphical Abstract
}

Chin. J. Catal., 2018, 39: 857-866 doi: 10.1016/S1872-2067(17)62919-X

\section{The relationship between the microstructures and catalytic behaviors of iron-oxygen precursors during direct coal liquefaction}

Jing Xie, Hanfeng Lu*, Geping Shu, Kejian Li, Xuwen Zhang, Hongxue Wang, Wang Yue, Shansong Gao, Yinfei Chen* Zhejiang University of Technology;

National Engineering Laboratory for Direct Coal Liquefaction, China Shenhua Coal to Liquid and Chemical Shanghai Research Institute
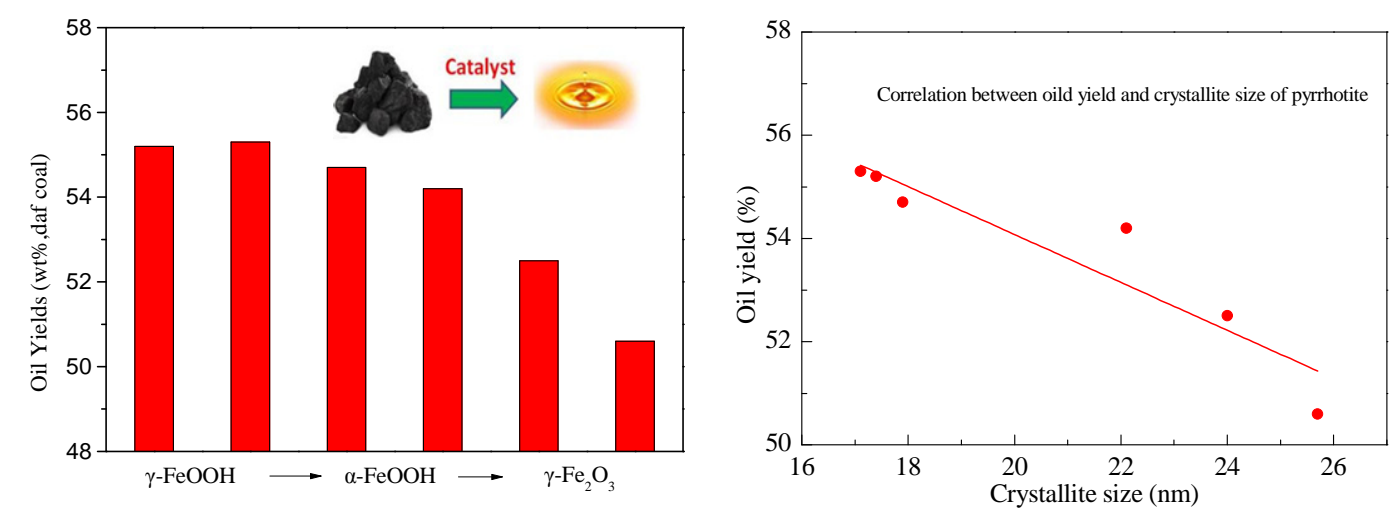

Precursors consisting of iron-oxygen compounds with $\gamma$-FeOOH or $\alpha$-FeOOH crystalline phases that are readily transformed into fine crystallites of pyrrhotite exhibit superior catalytic activity during direct coal liquefaction.

[14] I. Mochida, K. Sakanishi, Adv. Catal., 1994, 40, 39-85.

[15] I. Mochida, K. Sakanishi, N. Suzuki, M. Sakurai, Y. Tsukui, T. Kaneko, Catal. Surv. Jpn., 1998, 2, 17-30.

[16] T. Kaneko, F. Derbyshire, E. Makino, D. Gray, M. Tamura, K. J. Li, Coal Liquefaction, Ullmann's Encyclopedia of Industrial Chemistry, 7th ed., Wiley-VCH, Weinheim, 2012.

[17] M. Farcasiu, C. Smith, V. R. Pradhan, I. Wender, Fuel ProcessTechnol., 1991, 29, 199-208.

[18] B. Robert, Fuel, 2014, 117, 624-632.

[19] J. C. Linehan, D. W. Matson, J. G. Darab, Energy Fuels, 1994, 8, 56-62.

[20] T. Kaneko, K. Tazawa, N. Okuyama, M. Tamura, K. Shimasaki, Fuel, 2000, 79, 263-271.

[21] T. Kaneko, K. Tazawa, T. Koyama, K. Satoru, K. Shimasaki, Y. Kageyama, Energy Fuels, 1998, 12, 897-904.

[22] J. G. Darab, J. C. Linehan, D. W. Matson, Energy Fuels, 1994, 8, 1004-1005.

[23] J. M. Zhao, Z. Feng, F. E. Huggins, G. P. Huffman, Energy Fuels, 1994, $8,38-43$.

[24] Z. Feng, J. Zhao, F. E. Huggins, G. P. Huffman, J. Catal., 1993, 143, 510-519.
[25] A. V. Cugini, D. Krastman, D. V. Martello, E. F. Frommel, A. W. Wells, G. D. Holder, Energy Fuels, 1998, 8, 83-87.

[26] W. B. Li, G. P. Shu, K. J. Li, W. D. Huo, S. D. Shi, S. F. Du, P. He, Y. Wang, X. S. Zhu, CN patent 200410091 152.3, 2004.

[27] K. J. Li, X. Z. Wu, G. P. Shu, Clean Coal Technol, 2014, 20, 39-43.

[28] X. G. Shan, K. J. Li, D. X. Zhang, H. B. Jiang, H. X. Wen, Energy Fuels, 2015, 29, 2244-2249.

[29] K. Tanabe, S. Yokoyama, M. Satou, Y. Sanada, J. Jpn. Inst. Energy, 1986, 65, 1012-1019.

[30] X. Z. Wu, G. P. Shu, J. China Coal. Soc., 2009, 234, 1527-1530.

[31] X. Z. Wu, Clean Coal Technol, 2011, 17, 33-36.

[32] R. M. Cornell, U. Schwertmann, The Iron Oxides: Structure, Properties, Reactions, Occurences and Uses, 2nd ed., Wiley-VCH, Weinheim, 2004.

[33] T. Kaneko, K. Satoru, M. Tamura, K. Shimasaki, E. Makino, L. H. Silalahi, Fuel, 2002, 81, 1541-1549.

[34] J. Zieliński, I. Zglinicka, L. Znak, Z. Kaszkur, Appl. Catal. A, 2010, 381, 191-196.

[35] G. Djega-Mariadassou, M. Besson, D. Brodzki, H. Charcosset, T. Huu, J. Varloud, Fuel Process Technol., 1986, 12, 143-153.

[36] J. M. Lambert, G. Simkovich, P. L. Walke, Fuel, 1980, 59, 687-690.

\section{铁氧化物前驱体结构与其催化煤液化性能的关系}

\author{
谢 晶, ${ }^{\mathrm{a}, \mathrm{b}}$, 卢晗锋 ${ }^{\mathrm{a},}$, 舒歌平 ${ }^{\mathrm{b}}$, 李克健 ${ }^{\mathrm{b}}$, 章序文 ${ }^{\mathrm{b}}$, 王洪学 ${ }^{\mathrm{b}}$, 汪 月 ${ }^{\mathrm{a}}$, 高山松 ${ }^{\mathrm{b}}$, 陈银飞 ${ }^{\mathrm{a}, \#}$ \\ a浙江工业大学化学工程学院, 浙江杭州 310014 \\ ${ }^{b}$ 煤直接液化国家重点工程实验室, 中国神华煤制油化工有限公司上海研究院, 上海201108
}

摘要: 煤直接液化生产液体燃料是煤洁净转化和高效利用的一种重要途径, 是平衡富煤少油地区资源的有效技术手段. 高 效煤直接液化催化剂能够促进煤的热解, 加速热解大分子的加氢裂化, 提高液化产物中油的收率和油的品质. 各种含铁物 质如赤泥、天然铁矿石、合成型铁硫化物、合成型铁氧化物、以及油溶性和水溶性含铁物质都被用做了煤直接液化催化 剂的前驱体, 它们在煤液化条件下都能原位转化为磁黄铁矿相 $\left(\mathrm{Fe}_{1-\mathrm{x}} \mathrm{S}\right)$ 从而起到催化作用. 由于前驱体组成和性质差异, 原 
位生成的活性相的性质也会有较大差异, 导致煤液化结果有很大不同.

对前驱体的性质和其原位形成的活性相及其煤液化催化活性的关联研究, 对于催化剂前驱体的篮选、设计和生产都具 有非常重要的指导意义. 但由于影响煤液化结果的因素很多, 并且催化剂前驱体的来源、组成或制备条件的差异, 很难判 定前驱体的某一性质是影响煤液化催化活性的决定性因素, 更难以获得前驱体的晶相、晶粒度、比表面积、粒度等因素与 煤液化结果的趋势性关联关系. 我们采用相同的制备方法和相同的反应原料, 仅改变一个容易调变的温度参数, 成功制备 出同一体系且具有渐变微观结构的铁氧化合物前驱体, 并在高压釜内考察了硫化性质和对神华神东煤的催化液化活性, 通 过SEM, XRD, TG, BET和 $\mathrm{H}_{2}$-TPR等表征手段研究了不同温度合成的铁氧化物前驱体的微观结构与性质, 进而探索建立与 煤液化催化活性之间的关联. 结果发现, 铁氧化物的微观结构可以通过控制液相合成时的沉淀及氧化反应温度来调变, 铁 氧化物前驱体晶相是最重要的影响因素. 正是得益于包含较多的 $\gamma-\mathrm{FeOOH}$ 和 $\alpha-\mathrm{FeOOH}$ 晶相, 以及较大的比表面积, 较高的 含水量和更多的活性氧数量, 相比高温 $\left(70^{\circ} \mathrm{C}\right)$ 合成的铁氧化物低温 $\left(20-30{ }^{\circ} \mathrm{C}\right)$ 合成的铁氧化物油收率可提高 $4.5 \%-4.6 \%$. 原位生成的活性相磁黄铁矿相 $\left(\mathrm{Fe}_{1-x} \mathrm{~S}\right)$ 的结构由其前驱体决定, 其晶粒度与煤液化油收率呈近似线性对应关系, 表明磁黄铁 矿相晶粒度越低, 煤液化油收率越高.

最后我们以液化原料煤粉作为载体, 考察了不同合成温度对负载的铁氧化物前驱体的影响, 发现煤粉作为载体虽然不 会过分干扰合成温度对铁化合物的晶相、形貌的影响, 但可以起到良好的物理分散和降低铁氧化物前驱体粒度的作用, 是 改善煤液化性能的一种有效方式.

关键词: 煤直接液化; 铁氧化物; 煤负载催化剂; 合成温度; 铁基催化剂

收稿日期: 2017-11-25. 接受日期: 2017-12-19. 出版日期: 2018-04-05.

*通讯联系人. 电话: (0571)88320767; 电子信箱: luhf@zjut.edu.cn

\#通讯联系人. 电子信箱: yfchen@zjut.edu.cn

基金来源：神华集团科技创新项目(MZY-13-12); 国家重点研发计划(2016YFB0600303).

本文的英文电子版由Elsevier出版社在ScienceDirect上出版(http://www.sciencedirect.com/science/journal/18722067).

\section{《催化学报》进入中科院 JCR 期刊分区工程技术大类2区}

近日, 中国科学院文献情报中心发布 2016 年版中科院JCR期刊分区, Chinese Journal of Catalysis ( 《催化学 报》) 在工程技术类 1845 种期刊中排名第 354 位, 居工程技术大类 2 区. 中科院 JCR 期刊分区按照学术影响力 作为划分方式, 将每个学科的所有期刊按照学术影响力 (3年平均JCR影响因子 (IF)) 由高到低降序排列, 依次划 分为 4 个区, 使每个分区期刊影响力总和相同. 由于学科内期刊的 3 年IF的偏态分布, 这使得 1 区期刊数量极少. 为保证期刊 1 区期刊数量, 1 区期刊取整个学科数量总数的 $5 \%$, 即 3 年平均 $\mathrm{IF}$ 最高的 $5 \%$ 的期刊为 1 区期刊. $2-4$ 区 期刊使用 3年平均IF总和相同的方式划分 (分区方法详见https://www.fenqubiao.com).

近年, 《催化学报》的学术质量及影响力不断提升, 这是中国化学会催化委员会委员、《催化学报》编委、审 稿专家、作者和读者长期不解努力和共同支持的结果. 衷心感谢各位老师在期刊宣传、投稿原创性高质量稿件、 学术质量把关以及组约优秀稿件、组办高水平专刊等方面所给予的持续的、巨大的支持! 